\title{
EFFECTS OF CLAY FRACTION MINERALOGY ON PHYSICAL ATTRIBUTES OF A YELLOW ULTISOL TREATED WITH CHISELING
}

\author{
Deise C. S. Nogueira ${ }^{1 *}$, Carolina Fernandes ${ }^{1}$, Luma C. de Souza ${ }^{1}$, Lívia A. Camargo ${ }^{2}$, \\ Antonio S. Ferraudo ${ }^{1}$
}

${ }^{1 *}$ Corresponding author. Faculdade de Ciências Agrárias e Veterinárias (FCAV), Unesp/ Jaboticabal - SP, Brasil.
E-mail: deise17nogueira@hotmail.com | ORCID ID: https://orcid.org/0000-0003-3743-1712

\section{KEYWORDS}

iron oxides, kaolinite, soil bulk density, soil penetration resistance.

\begin{abstract}
The objective of this study was to evaluate the influence of minerals in the clay fraction on physical attributes of Yellow Ultisol cultivated with sugarcane and prepared with two different treatments: chiseling across the entire area and chiseling only in planting rows. The samples were collected from four layers of soil at eight months after planting. We assessed the texture of the soil, levels of iron extracted by dithionite-citrate-bicarbonate (DCB) and ammonium acid oxalate (AAO), ratio of kaolinite/(kaolinite + gibbsite), soil bulk density, and soil penetration resistance. The first area showed a higher ratio of kaolinite/(kaolinite + gibbsite) and the second area had greater levels of iron extracted by DCB. Levels of iron extracted by DCB were inversely correlated with soil bulk density and penetration resistance, while the kaolinite/(kaolinite + gibbsite) ratio was directly correlated with soil bulk density and penetration resistance. The area with a greater kaolinite/(kaolinite + gibbsite) ratio had higher values of soil bulk density and soil penetration resistance and the area with higher levels of iron showed lower values of soil bulk density and soil penetration resistance. The mineralogy influenced the soil's physical attributes, while soil preparation treatments did not.
\end{abstract}

\section{INTRODUCTION}

Sugarcane cultivation is economically significant in São Paulo, Brazil, owing to its use in the production of ethanol and sugar. Despite its central role in Brazilian agribusiness, sugarcane cultivation has brought about changes in soil bulk density (BD) and soil penetration resistance (SPR) due to compaction. Conventional sugarcane cultivation systems cause soil degradation through disaggregation, leading to soil compaction.

To minimize the effects caused by compaction, farmers have adopted less aggressive soil preparation practices in agricultural areas, such as chiseling only along planting rows. This practice improves the soil's physical qualities (Calonego et al., 2017) by increasing soil porosity and reducing soil bulk density (Nunes et al., 2014). As such, the effects of soil preparation on the physical attributes are also influenced by the mineralogy of the clay fraction.

The mineralogical composition of Brazilian Ultisols include varying proportions of iron oxides, gibbsite, and kaolinite, which in turn are related to the soil's physical attributes (Lu et al., 2014; Bonetti et al., 2017). Furthermore, Camargo et al. (2013) and Ramos et al. (2015) found high values of soil bulk density and penetration resistance in kaolinitic soils. Meanwhile, Manyala et al. (2015) and $\mathrm{Wu}$ et al. (2016) showed a correlation between BD and iron extracted by dithionitecitrate-bicarbonate (DCB) in Ultisols.

Know the mineral composition of the clay fraction will improve our understanding of the physical attributes of the soil. The objective of the current study was to assess the influence of minerals in the clay fraction on the physical attributes in a Yellow Ultisol cultivated with sugarcane and treated with two different preparation methods: chiseling across the entire area and chiseling only in planting rows.

\section{MATERIAL AND METHODS}

The study was undertaken in the municipality of Monte Alto, southwest São Paulo, Brazil (geographic

\footnotetext{
${ }^{1}$ Faculdade de Ciências Agrárias e Veterinárias (FCAV), Unesp/ Jaboticabal - SP, Brasil.

${ }^{2}$ Universidade de Campinas (Unicamp)/ Campinas - SP, Brasil.
} 
coordinates: $21^{\circ} 17^{\prime} 24^{\prime \prime} \mathrm{S}$ and $48^{\circ} 25^{\prime} 48^{\prime \prime} \mathrm{W}$; altitude of 735 $\mathrm{m})$. We identified an area of 9 hectares with a slope of $1.1 \%$ for the collection of 64 soil samples spaced approximately $132 \mathrm{~m}$ apart. Within the study area, a section at higher altitude (Area I, $648 \mathrm{~m}$ ) and a section at lower altitude (Area II, $640 \mathrm{~m}$ ) were identified and 32 samples were collected from each section to capture the greatest variability of the soil's clay fraction mineralogy (Camargo et al., 2014).

The climate of the region was classified as mesothermal (Thornthwaite B2rB' ${ }^{\mathrm{a}}$ ), with dry winters and temperatures in the hottest month greater than $22{ }^{\circ} \mathrm{C}$ and in the coldest month greater than $18{ }^{\circ} \mathrm{C}$. Annual average precipitation is $1,400 \mathrm{~mm}$, with rain concentrated in the period from October to March, and a relatively dry period from April to September.

The soil in the area is Yellow Ultisol and the parent material is identified as Vale do Rio do Peixe sandstone, formerly Bauru Adamantina Formation (IPT, 1981). Sugarcane has been cultivated in the study area for more than 20 years and mechanical harvesting has been used since 2004.

In half of the study area, the soil was prepared as follows: chiseling along the planting rows with tilling of the soil only in the sugarcane planting rows, thus preserving the soil between rows. In the other half of the study area, the entire area was subjected to chiseling and tilling was conducted along and between planting rows.

The sugarcane was planted using a planter with a potential of $220 \mathrm{hp}$ and weight of $10.540 \mathrm{~kg}$. Earthing-up, or ridging, was conducted one month after planting using a cultivator coupled to a tractor with a potential of $182 \mathrm{hp}$.

We collected disturbed and undisturbed soil samples along planting rows (at $0.20 \mathrm{~m}$ from the ridge) and between rows (at $0.75 \mathrm{~m}$ from the ridge) from the following layers: $0.00-0.10 \mathrm{~m}, 0.10-0.20 \mathrm{~m}, 0.20-0.40 \mathrm{~m}$, and $0.40-0.60 \mathrm{~m}$. The disturbed samples were collected with the help of a Dutch auger and used to examine soil texture (Claessen, 1997) and clay fraction minerals. The identification of clay fraction minerals began with clay separation using a centrifuge (Jackson, 1958) and removal of iron oxides was done using the method described by Mehra \& Jackson (1960). The levels of iron extracted using ammonium acid oxalate $\left(\mathrm{Fe}_{\mathrm{AAO}}\right)$ were determined based on the methodology proposed by Camargo et al. (1986). To assess the kaolinite (Kt) and gibbsite (Gb) surface areas, we used a Rigaku Mini-Flex II x-ray diffractometer with a copper cathode that had a nickel filter and $\mathrm{k} \alpha$ radiation $(20 \mathrm{~mA}, 30 \mathrm{Kv})$ on slides of powdered material. The procedure used was $2^{\circ} 2 \Theta /$ minute for the characterization of $\mathrm{Kt}$ and $\mathrm{Gb}$. The ratio of kaolinite/(kaolinite+gibbsite) $[\mathrm{Kt} /(\mathrm{Kt}+\mathrm{Gb})]$ was calculated based on the reflection areas of $\mathrm{Ct}(001)$ and $\mathrm{Gb}$ (002) of the diffractograms.

The undisturbed samples were collected using an Uhland sampler with volumetric rings $(0.05 \times 0.05 \mathrm{~m})$. From these samples, we determined soil BD (Embrapa, 1997) and SPR (Tormena et al., 1998).

Firstly, descriptive statistics were calculated, including mean, standard error, standard deviation, minimum, maximum, and coefficient of variation to determine the variability of the studied attributes. Subsequently, we conducted explorative multivariate analyses with hierarchical grouping (data not shown) and principal component analysis (PCA). For these analyses, we selected only the variables that were not collinear. After selection, variables were standardized (null mean and unit variance). Hotelling's $\mathrm{T}^{2}$ test was conducted to check for significant differences $(\mathrm{p}<0.05)$ between the groups observed in the analysis.

We only considered the principal components whose eigenvalues were greater than unity according to the criteria established by Kaiser (1958). The coefficients of the linear functions that define the main component were used in their interpretation, with the sign and relative size of the coefficients as an indication of the weight to be assigned to each variable. Only coefficients with high values (absolute value greater than or equal to 0.60 ) were considered for interpretation. The multivariate analysis was conducted using the program Statistica 7.0.

\section{RESULTS AND DISCUSSION}

We found that the higher altitude (Area I) section was characterized by a greater ratio of kaolinite/(kaolinite+gibbsite) $[\mathrm{Kt} /(\mathrm{Kt}+\mathrm{Gb})]$ and lower levels of iron extracted by dithionite-citrate-bicarbonate $\left(\mathrm{Fe}_{\mathrm{DCB}}\right)$ and by ammonium acid oxalate $\left(\mathrm{Fe}_{\mathrm{AAO}}\right)$ compared to the lower altitude (Area II) section (Table 1). This mineralogical difference in the two areas can be attributed to the effect of relief on the formation of soil characteristics (Camargo et al., 2014). Due to its impact on the flow of water, relief influences chemical reactions and the transport of materials through soil with different mineralogical compositions (Ghidin et al., 2006). Thus, variations in topography produce internal drainage conditions that affect the movement and redistribution of clay minerals (Campos et al., 2012). 
TABLE 1. Descriptive statistics, including Standard Error (SE), Standard Deviation (SD), Minimum (Min), Maximum (Max), Coefficient of Variation (CV), of the studied attributes.

\begin{tabular}{|c|c|c|c|c|c|c|c|c|c|c|c|c|}
\hline \multirow{3}{*}{ Attribute } & Mean & $\mathrm{SE}$ & $\mathrm{SD}$ & Min & $\operatorname{Max}$ & CV $(\%)$ & Mean & $\mathrm{SE}$ & $\mathrm{SD}$ & Min & Max & CV $(\%)$ \\
\hline & \multicolumn{6}{|c|}{ Area I } & \multicolumn{6}{|c|}{ Area II } \\
\hline & \multicolumn{6}{|c|}{ Depth $0.00-0.10 \mathrm{~m}$} & \multicolumn{6}{|c|}{ Depth $0.00-0.10 \mathrm{~m}$} \\
\hline Clay $\left(\mathrm{g} \mathrm{kg}^{-}\right.$ & 117 & 2 & 7 & 110 & 129 & 6 & 145 & 3 & 10 & 129 & 157 & 7 \\
\hline Silt $\left(\mathrm{g} \mathrm{kg}^{-1}\right)$ & 76 & 5 & 14 & 48 & 91 & 19 & 57 & 4 & 12 & 37 & 68 & 21 \\
\hline Sand $\left(\mathrm{g} \mathrm{kg}^{-}\right.$ & 807 & 5 & 13 & 790 & 836 & 2 & 798 & 4 & 10 & 781 & 810 & 1 \\
\hline $\mathrm{Fe}_{\mathrm{DCB}}\left(\mathrm{g} \mathrm{kg}^{-}\right.$ & 17 & 0.22 & 0.61 & 16 & 18 & 4 & 20 & 1 & 3 & 16 & 23 & 14 \\
\hline $\mathrm{Fe}_{\mathrm{AAO}}\left(\mathrm{g} \mathrm{kg}^{-}\right.$ & 0.71 & 0.13 & 0.36 & 0.43 & 1 & 51 & 0.92 & 0.11 & 0.31 & 0.64 & 2 & 33 \\
\hline \multirow[t]{2}{*}{$\mathrm{Kt} / \mathrm{Kt}+\mathrm{Gb}$} & 0.74 & 0.03 & 0.07 & 0.62 & 0.83 & 10 & 0.56 & 0.02 & 0.06 & 0.46 & 0.65 & 11 \\
\hline & \multicolumn{6}{|c|}{ Depth $0.10-0.20 \mathrm{~m}$} & \multicolumn{6}{|c|}{ Depth $0.10-0.20 \mathrm{~m}$} \\
\hline Clay $\left(\mathrm{g} \mathrm{kg}^{-}\right.$ & 138 & 5 & 14 & 116 & 161 & 10 & 157 & 5 & 14 & 136 & 176 & 9 \\
\hline Silt $\left(\mathrm{g} \mathrm{kg}^{-1}\right)$ & 92 & 10 & 27 & 48 & 122 & 30 & 86 & 5 & 14 & 67 & 108 & 16 \\
\hline Sand $\left(\mathrm{g} \mathrm{kg}^{-}\right.$ & 770 & 12 & 35 & 741 & 836 & 5 & 757 & 3 & 9 & 746 & 770 & 1 \\
\hline $\mathrm{Fe}_{\mathrm{DCB}}\left(\mathrm{g} \mathrm{kg}^{-}\right.$ & 18 & 0.73 & 2 & 14 & 20 & 12 & 20 & 1 & 3 & 16 & 25 & 17 \\
\hline $\mathrm{Fe}_{\mathrm{AAO}}\left(\mathrm{g} \mathrm{kg}^{-}\right.$ & 0.64 & 0.07 & 0.18 & 0.40 & 0.91 & 28 & 0.87 & 0.09 & 0.25 & 0.50 & 1 & 28 \\
\hline \multirow[t]{2}{*}{$\mathrm{Kt} / \mathrm{Kt}+\mathrm{Gb}$} & 0.79 & 0.01 & 0.03 & 0.74 & 0.84 & 4 & 0.60 & 0.02 & 0.06 & 0.54 & 0.73 & 10 \\
\hline & \multicolumn{6}{|c|}{ Depth $0.20-0.40 \mathrm{~m}$} & \multicolumn{6}{|c|}{ Depth $0.20-0.40 \mathrm{~m}$} \\
\hline Clay $\left(\mathrm{g} \mathrm{kg}^{-}\right.$ & 186 & 6 & 16 & 160 & 205 & 9 & 189 & 5 & 14 & 161 & 206 & 8 \\
\hline Silt $\left(\mathrm{g} \mathrm{kg}^{-1}\right)$ & 75 & 10 & 28 & 43 & 119 & 37 & 80 & 8 & 22 & 62 & 120 & 28 \\
\hline Sand $\left(\mathrm{g} \mathrm{kg}^{-}\right.$ & 738 & 5 & 15 & 710 & 758 & 2 & 731 & 6 & 17 & 694 & 748 & 2 \\
\hline $\mathrm{Fe}_{\mathrm{DCB}}(\mathrm{g}$ & 19 & 0.60 & 2 & 16 & 22 & 9 & 22 & 1 & 3 & 19 & 27 & 13 \\
\hline $\mathrm{Fe}_{\mathrm{AAO}}\left(\mathrm{g} \mathrm{kg}^{-}\right.$ & 0.58 & 0.04 & 0.12 & 0.38 & 0.74 & 20 & 0.84 & 0.14 & 0.38 & 0.33 & 2 & 45 \\
\hline \multirow[t]{2}{*}{$\mathrm{Kt} / \mathrm{Kt}+\mathrm{Gb}$} & 0.81 & 0.02 & 0.05 & 0.74 & 0.87 & 7 & 0.61 & 0.04 & 0.12 & 0.43 & 0.84 & 19 \\
\hline & \multicolumn{6}{|c|}{ Depth $0.40-0.60 \mathrm{~m}$} & \multicolumn{6}{|c|}{ Depth $0.40-0.60 \mathrm{~m}$} \\
\hline Clay $\left(\mathrm{g} \mathrm{kg}^{-}\right.$ & 262 & 7 & 19 & 231 & 290 & 7 & 249 & 6 & 17 & 222 & 272 & 7 \\
\hline Silt $\left(\mathrm{g} \mathrm{kg}^{-1}\right)$ & 53 & 9 & 26 & 11 & 96 & 49 & 58 & 8 & 23 & 30 & 97 & 39 \\
\hline Sand $\left(\mathrm{g} \mathrm{kg}^{-}\right.$ & 685 & 8 & 24 & 644 & 707 & 3 & 693 & 6 & 16 & 661 & 709 & 2 \\
\hline $\mathrm{Fe}_{\mathrm{DCB}}\left(\mathrm{g} \mathrm{kg}^{-}\right.$ & 24 & 1 & 4 & 19 & 29 & 15 & 24 & 0.96 & 3 & 21 & 28 & 11 \\
\hline $\mathrm{Fe}_{\mathrm{AAO}}\left(\mathrm{g} \mathrm{kg}^{-}\right.$ & 0.56 & 0.63 & 0.18 & 0.40 & 0.84 & 32 & 0.69 & 0.09 & 0.25 & 0.38 & 1 & 36 \\
\hline $\mathrm{Kt} / \mathrm{Kt}+\mathrm{Gb}$ & 0.77 & 0.02 & 0.06 & 0.68 & 0.86 & 8 & 0.55 & 0.03 & 0.08 & 0.40 & 0.65 & 15 \\
\hline
\end{tabular}

In Area I, we found a mean clay content of $262 \mathrm{~g}$ $\mathrm{kg}^{-1}$ and mean sand content of $807 \mathrm{~g} \mathrm{~kg}^{-1}$. In Area II, the clay content was on average $249 \mathrm{~g} \mathrm{~kg}^{-1}$ and a similar mean of $798 \mathrm{~g} \mathrm{~kg}^{-1}$ was found for sand (Table 1). The levels of sand observed can be attributed to the parent material of the study area. Montanari et al. (2010) showed similar variations in Latosols with parent material comparable to the current study.

In the two study areas, we found an increase in the clay content and a decrease in the sand content with increasing depth (Table 1). These results are consistent with past observations of increased clay with depth that occurs in Ultisols and is attributed to the mobilization and loss of clay from superior to inferior layers (Campos et al., 2012; Suzuki et al., 2014).

The soil bulk density (BD) (Table 2) and soil penetration resistance (SPR) (Table 3) were greater in Area I than Area II. It is important to highlight that the two study areas received the same soil preparation treatment, localized chiseling and chiseling across the entire area; the collection of soil samples were also carried out during the same period for the two areas, at eight months after soil preparation. As such, differences in physical attributes are a reflection of differences in mineralogy in the two areas. 
TABLE 2. Descriptive statistics, including Standard Error (SE), Standard Deviation (SD), Minimum (Min), Maximum (Max), Coefficient of Variation (CV), of soil bulk density $\left(\mathrm{Mg} \mathrm{m}^{-3}\right)$.

\begin{tabular}{|c|c|c|c|c|c|c|c|c|c|c|c|c|}
\hline & Mean & SE & SD & Min & Max & CV $(\%)$ & Mean & $\mathrm{SE}$ & SD & Min & Max & CV (\%) \\
\hline Depth (m) & \multicolumn{6}{|c|}{ Area I } & \multicolumn{6}{|c|}{ Area II } \\
\hline \multicolumn{7}{|c|}{ Chiseling in planting rows } & \multicolumn{6}{|c|}{ Chiseling in planting rows } \\
\hline \multicolumn{7}{|c|}{ Sample from row } & \multicolumn{6}{|c|}{ Sample from row } \\
\hline $0.00-0.10$ & 1.64 & 0.09 & 0.12 & 1.56 & 1.73 & 7.34 & 1.49 & 0.03 & 0.04 & 1.47 & 1.52 & 2.42 \\
\hline $0.10-0.20$ & 1.84 & 0.08 & 0.11 & 1.76 & 1.92 & 6.15 & 1.64 & 0.02 & 0.03 & 1.62 & 1.66 & 1.80 \\
\hline $0.20-0.40$ & 1.80 & 0.09 & 0.14 & 1.70 & 1.90 & 7.70 & 1.67 & 0.04 & 0.06 & 1.63 & 1.71 & 3.69 \\
\hline $0.40-0.60$ & 1.77 & 0.10 & 0.14 & 1.67 & 1.87 & 8.06 & 1.75 & 0.07 & 0.09 & 1.69 & 1.82 & 5.26 \\
\hline \multicolumn{7}{|c|}{ Sample from between rows } & \multicolumn{6}{|c|}{ Sample from between rows } \\
\hline $0.00-0.10$ & 1.67 & 0.09 & 0.13 & 1.58 & 1.77 & 7.88 & 1.30 & 0.34 & 0.48 & 0.96 & 1.63 & 36.64 \\
\hline $0.10-0.20$ & 1.88 & 0.04 & 0.05 & 1.84 & 1.92 & 2.91 & 1.76 & 0.08 & 0.12 & 1.68 & 1.84 & 6.54 \\
\hline $0.20-0.40$ & 1.85 & 0.04 & 0.06 & 1.81 & 1.89 & 3.25 & 1.84 & 0.03 & 0.05 & 1.81 & 1.87 & 2.49 \\
\hline $0.40-0.60$ & 1.72 & 0.09 & 0.14 & 1.62 & 1.82 & 8.17 & 1.72 & 0.02 & 0.03 & 1.70 & 1.74 & 1.72 \\
\hline \multicolumn{7}{|c|}{ Chiseling in total area } & \multicolumn{6}{|c|}{ Chiseling in total area } \\
\hline \multicolumn{7}{|c|}{ Sample from row } & \multicolumn{6}{|c|}{ Sample from row } \\
\hline $0.00-0.10$ & 1.71 & 0.01 & 0.02 & 1.70 & 1.72 & 1.02 & 1.77 & 0.00 & 0.00 & 1.76 & 1.77 & 0.28 \\
\hline $0.10-0.20$ & 1.84 & 0.00 & 0.00 & 1.83 & 1.84 & 0.20 & 1.82 & 0.07 & 0.10 & 1.75 & 1.89 & 5.51 \\
\hline $0.20-0.40$ & 1.77 & 0.00 & 0.00 & 1.77 & 1.78 & 0.17 & 1.78 & 0.10 & 0.14 & 1.68 & 1.87 & 7.63 \\
\hline $0.40-0.60$ & 1.82 & 0.07 & 0.10 & 1.75 & 1.89 & 5.28 & 1.80 & 0.05 & 0.07 & 1.75 & 1.85 & 4.04 \\
\hline \multicolumn{7}{|c|}{ Sample from between rows } & \multicolumn{6}{|c|}{ Sample from between rows } \\
\hline $0.00-0.10$ & 1.68 & 0.03 & 0.04 & 1.65 & 1.71 & 2.28 & 1.71 & 0.00 & 0.01 & 1.71 & 1.71 & 0.30 \\
\hline $0.10-0.20$ & 1.89 & 0.00 & 0.00 & 1.89 & 1.89 & 0.05 & 1.86 & 0.02 & 0.03 & 1.84 & 1.88 & 1.79 \\
\hline $0.20-0.40$ & 1.89 & 0.03 & 0.05 & 1.86 & 1.93 & 2.59 & 1.74 & 0.10 & 0.14 & 1.64 & 1.84 & 8.06 \\
\hline $0.40-0.60$ & 1.86 & 0.08 & 0.11 & 1.78 & 1.94 & 6.11 & 1.79 & 0.07 & 0.10 & 1.72 & 1.87 & 5.64 \\
\hline
\end{tabular}

TABLE 3. Descriptive statistics, including Standard Error (SE), Standard Deviation (SD), Minimum (Min), Maximum (Max), Coefficient of Variation (CV), of soil penetration resistance (MPa).

\begin{tabular}{|c|c|c|c|c|c|c|c|c|c|c|c|c|}
\hline Depth $(\mathrm{cm})$ & Mean & EPM & $\mathrm{DP}$ & Mínnnn. & Máx. & CV (\%) & Mean & EPM & DP & Mín. & Máx. & $\mathrm{CV}(\%)$ \\
\hline \multicolumn{7}{|c|}{ Area I } & \multicolumn{6}{|c|}{ Area II } \\
\hline \multicolumn{7}{|c|}{ Chiseling in planting rows } & \multicolumn{6}{|c|}{ Chiseling in planting rows } \\
\hline \multicolumn{7}{|c|}{ Sample from row } & \multicolumn{6}{|c|}{ Sample from row } \\
\hline $0.0-0.10$ & 1.66 & 0.16 & 0.23 & 1.50 & 1.82 & 13.63 & 0.79 & 0.33 & 0.47 & 0.46 & 1.12 & 59.07 \\
\hline $0.10-0.20$ & 3.09 & 0.89 & 1.26 & 2.20 & 3.98 & 40.73 & 1.28 & 0.05 & 0.07 & 1.23 & 1.33 & 5.52 \\
\hline $0.20-0.40$ & 2.69 & 0.96 & 1.36 & 1.73 & 3.65 & 50.47 & 1.36 & 0.16 & 0.23 & 1.20 & 1.52 & 16.64 \\
\hline $0.40-0.60$ & 2.00 & 0.68 & 0.96 & 1.33 & 2.68 & 47.61 & 2.19 & 0.96 & 1.36 & 1.23 & 3.15 & 61.99 \\
\hline \multicolumn{7}{|c|}{ Sample from between rows } & \multicolumn{6}{|c|}{ Sample from between rows } \\
\hline $0.0-0.10$ & 2.30 & 0.21 & 0.29 & 2.10 & 2.51 & 12.74 & 1.46 & 0.42 & 0.59 & 1.04 & 1.87 & 40.34 \\
\hline $0.10-0.20$ & 3.98 & 0.89 & 1.26 & 3.09 & 4.87 & 31.57 & 2.68 & 0.38 & 0.54 & 2.30 & 3.06 & 20.05 \\
\hline $0.20-0.40$ & 3.08 & 0.04 & 0.05 & 3.05 & 3.12 & 1.63 & 3.61 & 0.60 & 0.85 & 3.01 & 4.21 & 23.50 \\
\hline $0.40-0.60$ & 1.78 & 0.74 & 1.05 & 1.04 & 2.52 & 59.10 & 2.27 & 0.46 & 0.64 & 1.81 & 2.72 & 28.41 \\
\hline \multicolumn{7}{|c|}{ Chiseling in total area } & \multicolumn{6}{|c|}{ Chiseling in total area } \\
\hline \multicolumn{7}{|c|}{ Sample from row } & \multicolumn{6}{|c|}{ Sample from row } \\
\hline $0.0-0.10$ & 1.97 & 0.11 & 0.16 & 1.86 & 2.08 & 7.90 & 1.96 & 0.72 & 1.02 & 1.24 & 2.68 & 51.95 \\
\hline $0.10-0.20$ & 2.96 & 0.18 & 0.25 & 2.78 & 3.13 & 8.38 & 2.30 & 0.75 & 1.06 & 1.55 & 3.05 & 46.12 \\
\hline $0.20-0.40$ & 1.65 & 0.59 & 0.83 & 1.06 & 2.23 & 50.29 & 1.93 & 0.34 & 0.48 & 1.59 & 2.27 & 24.91 \\
\hline $0.40-0.60$ & 1.96 & 0.58 & 0.81 & 1.38 & 2.53 & 41.59 & 1.90 & 0.25 & 0.35 & 1.65 & 2.14 & 18.28 \\
\hline \multicolumn{7}{|c|}{ Sample from between rows } & \multicolumn{6}{|c|}{ Sample from between rows } \\
\hline $0.0-0.10$ & 2.15 & 0.03 & 0.04 & 2.12 & 2.18 & 1.97 & 2.30 & 0.45 & 0.64 & 1.85 & 2.75 & 27.67 \\
\hline $0.10-0.20$ & 3.66 & 0.51 & 0.72 & 3.15 & 4.17 & 19.71 & 2.80 & 0.43 & 0.61 & 2.37 & 3.23 & 21.72 \\
\hline $0.20-0.40$ & 2.79 & 0.59 & 0.83 & 2.20 & 3.38 & 29.91 & 2.13 & 0.02 & 0.02 & 2.11 & 2.14 & 1.00 \\
\hline $0.40-0.60$ & 4.13 & 1.11 & 1.56 & 3.03 & 5.24 & 37.79 & 2.08 & 0.53 & 0.74 & 1.55 & 2.60 & 35.78 \\
\hline
\end{tabular}


Area I showed a greater presence of kaolinite (Table 1), which can influence BD and SPR. The higher values of $\mathrm{BD}$ and SPR have been observed in a kaolinitic soil by Souza et al., 2009. According to Ajayi et al. (2009) kaolinitic soils have higher $\mathrm{BD}$ as a consequence of the face to face arrangement of microscopic kaolinite plates in soil, which consequently had higher values of SPR. On the contrary, in Area II, we found lower levels of BD (Table 2) and SPR (Table 3) in comparison to those in Area I. This behavior could be the result of increased levels of iron oxides in this area (Table 1). Iron oxides are cementing agents that are important in the process of soil aggregation (Inda et al., 2013; Bahia et al., 2014); therefore, greater levels of these minerals in the soil result in a more random arrangement of the particles, which is reflected in a more granular structure (Resende et al., 2005). This granular structure produced soils with lower BD and SPR when compared with soils with a higher presence of kaolinite (Ajayi et al., 2009).

We found that the coefficient of variation $(\mathrm{CV})$ of the SPR in Area I was greater in comparison to that in Area II (Table 3). These results suggest a relationship between the minerals of the clay fraction and the variation in of SPR, since the greater CV observed in Area I compared to that in Area II can be attributed to the kaolinitic mineralogy found in this area, consistent with the results above.

\section{Multivariate Analysis}

When we conducted the hierarchical grouping analysis, we found two distinct groups: Group 1 is composed of Area I (with a predominance of $\mathrm{Kt} /(\mathrm{Kt}+\mathrm{Gb})$ ratio), and Group 2 composed of Area II (with a predominance of $\left.\mathrm{Fe}_{\mathrm{DCB}}\right)$. After the exploratory analysis, we conducted a Hotelling's $\mathrm{T}^{2}$ test to confirm the difference between the two groups as a function of the depths studied. We found significant effects for Area I and Area II at depth $1(\mathrm{~F}=7.32 ; \mathrm{p}=0.0004)$, depth $2(\mathrm{~F}=$ $3.609 ; \mathrm{p}=0.041)$, depth $3(\mathrm{~F}=6.47 ; \mathrm{p}=0.0006)$, and depth $4(\mathrm{~F}=6.09 ; \mathrm{p}=0.008)$. These results support the separation of the areas based on the mineralogy of the soil as discussed above.

For the principal component analysis in layer 0.00 $0.10 \mathrm{~m}$, the principal components 1 and 2 explained $79 \%$ of the variability contained in the original variables ( $\mathrm{PC} 1$ $49 \%$ and $\mathrm{PC} 230 \%$ ) (Table 4). We found that PC1, involved a combination of variables $\mathrm{Kt} /(\mathrm{Kt}+\mathrm{Gb})$ ratio, $\mathrm{Fe}_{\mathrm{DCB}}$, clay, and sand content. The variables sand content and $\mathrm{Kt} /(\mathrm{Kt}+\mathrm{Gb})$ ratio showed a direct correlation, while an inverse correlation of these variables was found with clay content and $\mathrm{Fe}_{\mathrm{DCB}}$ (Table 4).

TABLE 4. Correlations of the variables soil penetration resistance (SPR), kaolinite/(kaolinite+gibbsite) ratio $[\mathrm{Kt} /(\mathrm{Kt}+\mathrm{Gb})]$, iron extracted by dithionite-citrate-bicarbonate $\left(\mathrm{Fe}_{\mathrm{DCB}}\right)$, clay content, sand content, and soil bulk density (BD) with the principal components for four depths.

\begin{tabular}{|c|c|c|}
\hline \multirow{2}{*}{ Variables } & PC1 $(49 \%)^{*}$ & PC2 $(30 \%)^{*}$ \\
\hline & \multicolumn{2}{|c|}{ Depth $0.00-0.10 \mathrm{~m}$} \\
\hline SPR & -0.17 & -0.85 \\
\hline$[\mathrm{Kt} /(\mathrm{Kt}+\mathrm{Gb})]$ & 0.67 & -0.44 \\
\hline $\mathrm{Fe}_{\mathrm{DCB}}$ & -0.95 & 0.11 \\
\hline Clay & -0.85 & -0.09 \\
\hline Sand & 0.91 & 0.23 \\
\hline \multirow[t]{2}{*}{$\mathrm{BD}$} & 0.03 & -0.89 \\
\hline & \multicolumn{2}{|c|}{ Depth $0.10-0.20 \mathrm{~m}$} \\
\hline & PC1 $(66 \%)$ & PC2 (15\%) \\
\hline SPR & -0.87 & -0.32 \\
\hline$[\mathrm{Kt} /(\mathrm{Kt}+\mathrm{Gb})]$ & -0.65 & -0.53 \\
\hline $\mathrm{Fe}_{\mathrm{DCB}}$ & 0.87 & -0.29 \\
\hline Clay & 0.89 & -0.30 \\
\hline Sand & -0.74 & 0.49 \\
\hline \multirow[t]{3}{*}{ BD } & -0.83 & -0.32 \\
\hline & \multicolumn{2}{|c|}{ Depth $0.20-0.40 \mathrm{~m}$} \\
\hline & $\mathrm{PC} 1(50 \%)^{*}$ & PC2 $(26 \%)^{*}$ \\
\hline SPR & -0.30 & -0.85 \\
\hline$[\mathrm{Kt} /(\mathrm{Kt}+\mathrm{Gb})]$ & -0.53 & 0.49 \\
\hline $\mathrm{Fe}_{\mathrm{DCB}}$ & 0.85 & -0.03 \\
\hline Clay & 0.87 & -0.14 \\
\hline Sand & -0.86 & 0.33 \\
\hline \multirow[t]{3}{*}{$\mathrm{BD}$} & -0.65 & -0.69 \\
\hline & \multicolumn{2}{|c|}{ Depth $0.40-0.60 \mathrm{~m}$} \\
\hline & PC1 $(52 \%)^{*}$ & PC2 $(20 \%)^{*}$ \\
\hline SPR & -0.75 & -0.36 \\
\hline$[\mathrm{Kt} /(\mathrm{Kt}+\mathrm{Gb})]$ & -0.31 & -0.77 \\
\hline $\mathrm{Fe}_{\mathrm{DCB}}$ & 0.81 & -0.11 \\
\hline Clay & 0.70 & -0.63 \\
\hline Sand & -0.81 & 0.18 \\
\hline $\mathrm{BD}$ & -0.81 & -0.20 \\
\hline
\end{tabular}

*Value refers to the percent of variation of the original group of data taken for the respective principal components. Correlations in bold $(>0.60$ of absolute value) are considered in the interpretation. 
The biplot (Figure 1) enabled us to identify the variables that contributed the most to the characterization of both study areas. The sand content and $\mathrm{Kt} /(\mathrm{Kt}+\mathrm{Gb})$ ratio helped to characterize Area I, indicating that the area consisted of higher levels of these attributes. On the contrary, the variables $\mathrm{Fe}_{\mathrm{DCB}}$ and clay content characterized Area II, which had higher levels of these attributes and lower levels of sand content and $\mathrm{Kt} /(\mathrm{Kt}+\mathrm{Gb})$ ratio. The dispersion of the variables for the two areas were located in opposite directions in the biplot. We found that the variables sand content and $\mathrm{Kt} /(\mathrm{Kt}+\mathrm{Gb})$ ratio had inverse correlations with the clay content and $\mathrm{Fe}_{\mathrm{DCB}}$. These inverse correlations can be attributed to the environments ability to form kaolinite, which is complicated by the presence of iron oxides. A higher level of iron oxide in the clay fraction caused disorganization in the kaolinite structure as the iron impedes the crystallization of the mineral (Mestdagh et al., 1980; Camargo et al., 2014). In other words, it disrupts the face to face adjustment of microscopic kaolinite plates, thus explaining the inverse relationship observed between $\mathrm{Fe}_{\mathrm{DCB}}$ and $\mathrm{Kt} /(\mathrm{Kt}+\mathrm{Gb})$ ratio in the present study. The direct correlation between the sand content and $\mathrm{Kt} /(\mathrm{Kt}+\mathrm{Gb})$ ratio is due to the fact that soils with high levels of sand liberate silica and contribute to the formation of kaolinite. According to Drees et al. (1989), the presence of mineral quartz in the clay fraction is common. Through weathering, the silicate minerals facilitate the recombination of $\mathrm{Si}$ with $\mathrm{Al}$ results in kaolinite formation (Ryan \& Huertas 2013).

- Área I - Área II

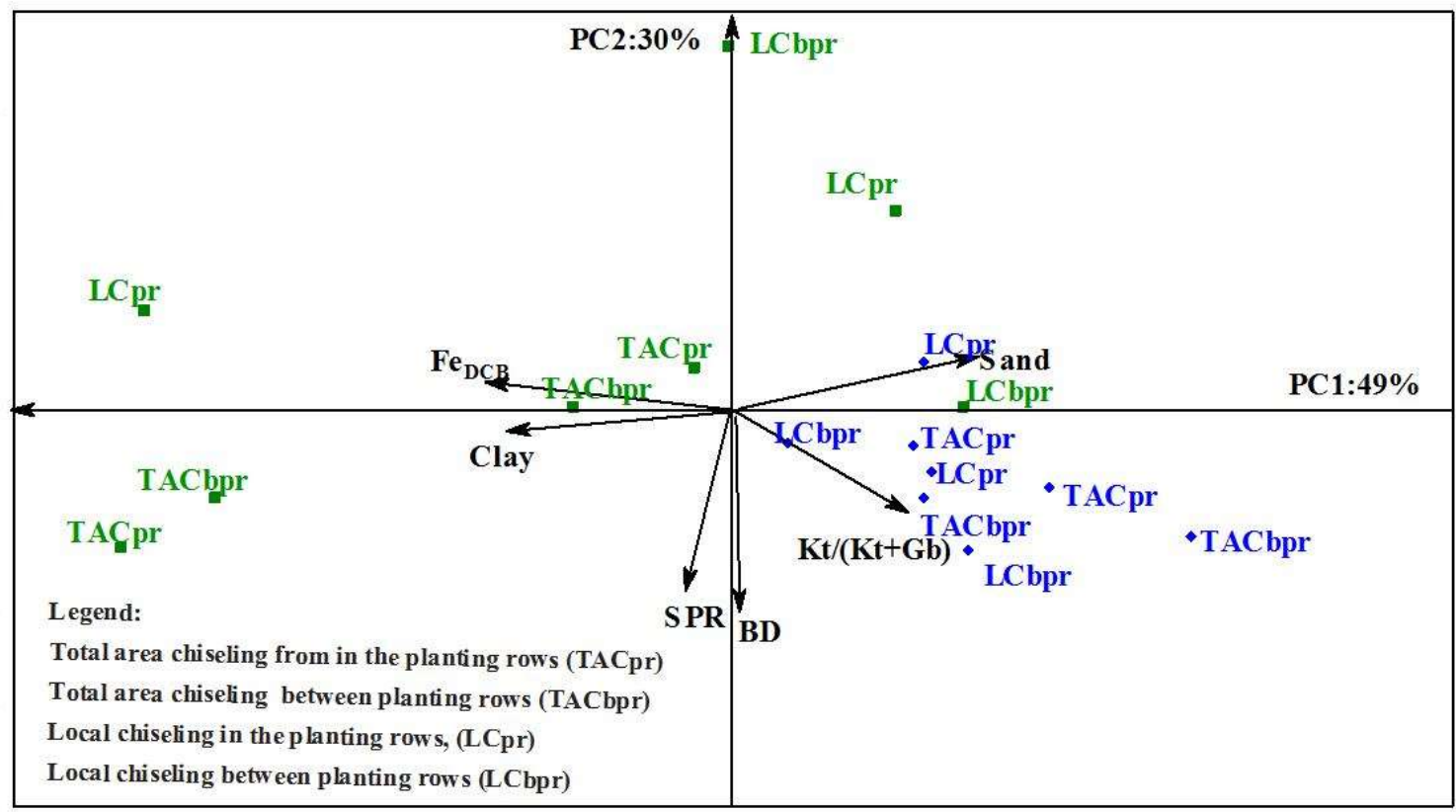

FIGURE 1. Graph showing the principal components PC1 and PC2 for the layer $0.0-0.10 \mathrm{~m}$, with the variables: soil penetration resistance (SPR), soil bulk density (BD), clay content, sand content, $\mathrm{Kt} /(\mathrm{Kt}+\mathrm{Gb})$ ratio and iron extracted by dithionite-citrate-bicarbonate $\left(\mathrm{Fe}_{\mathrm{DCB}}\right)$.

The relationship between the level of $\mathrm{Fe}_{\mathrm{DCB}}$ and the clay content observed herein supports the results found between these variables in the study by Camargo et al. (2014).

Considering the results presented in Table 4, in layer $0.10-0.20 \mathrm{~m}$, the principal components explained $81 \%$ of the total variability in the data $\mathrm{PC} 166 \%$ and $\mathrm{PC} 2$ $15 \%$ ). In this layer, PC1 included the participation of SPR, $\mathrm{Kt} /(\mathrm{Kt}+\mathrm{Gb})$ ratio, $\mathrm{Fe}_{\mathrm{DCB}}$, clay content, sand content, and $\mathrm{BD}$, as these variables provided greater discriminatory power (Table 4). The BD and SPR showed a direct correlation with $\mathrm{Kt} /(\mathrm{Kt}+\mathrm{Gb})$ ratio and sand content; however, BD and SPR were inversely correlated with the clay content and $\mathrm{Fe}_{\mathrm{DCB}}$. Area I can be characterized mineralogically by kaolinite (Figure 2) and the plate structure that it is associated with it was reflected in soils with greater levels of BD and SPR. Camargo et al. (2013) and Ramos et al. (2015) also observed higher levels of BD and SPR in kaolinitic soils. The increase of BD and SPR were evidences of soil compaction because it makes the movement of air and water through soil profile very difficult (Chen et al., 2014). As such, owing to its highly kaolinitic mineralogy, the soil of Area I is more susceptible to compaction. 
- Área I - Área II

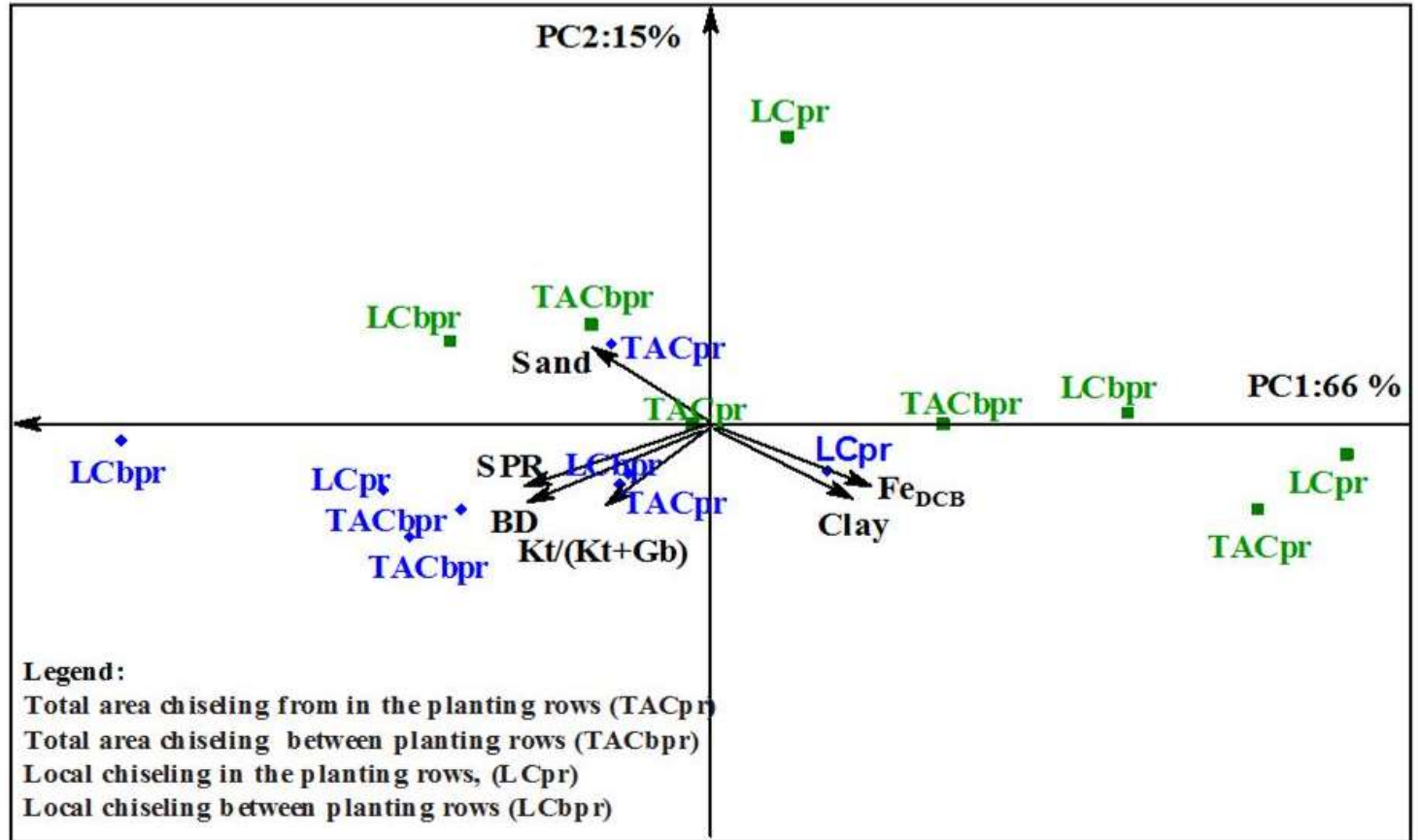

FIGURE 2. Graph of the principal components $\mathrm{PC} 1$ and $\mathrm{PC} 2$ in $0.10-0.20 \mathrm{~m}$ layer, with the variables: soil penetration resistance (SPR), soil bulk density (BD), clay content, sand content, $\mathrm{Kt} /(\mathrm{Kt}+\mathrm{Gb})$ ratio and iron extracted by dithionite-citratebicarbonate $\left(\mathrm{Fe}_{\mathrm{DCB}}\right)$.

Area II had an oxidic mineralogy owing to its characterization by $\mathrm{Fe}_{\mathrm{DCB}}$ (Figure 2). The iron oxides improved aggregation due to their cementing activity among soil particles (Regelink et al., 2015), resulting in improved soil porosity that produced lower values of $\mathrm{BD}$ (Camargo et al., 2014), and consequently SPR. Camargo et al. (2013) and Manyala et al. (2015) also observed a direct correlation between $\mathrm{Fe}_{\mathrm{DCB}}$ and $\mathrm{BD}$ and SPR. The oxidic mineralogy of Area II reduced BD and SPR, and therefore improved the soil's physical quality (Pezarico et al., 2013) which was reflected in soils that were less susceptible to the processes of compaction.

- Área I - Área II

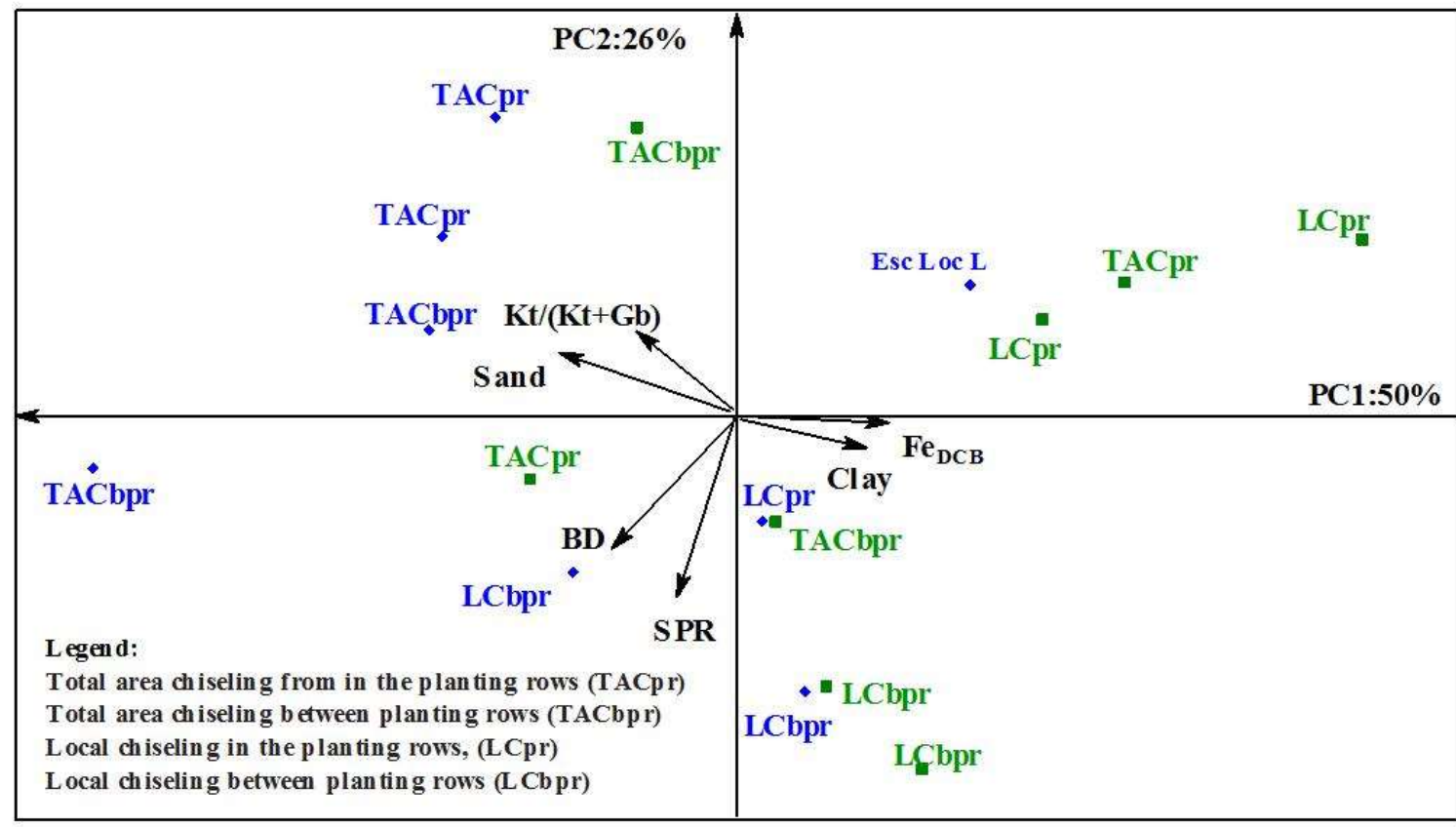

FIGURE 3. Graph of the principal components PC1 and PC2 in $0.20-0.40 \mathrm{~m}$ layer, with the variables: soil penetration resistance (SPR), soil bulk density (BD), clay content, sand content, $\mathrm{Kt} /(\mathrm{Kt}+\mathrm{Gb})$ ratio and iron extracted by dithionite-citratebicarbonate $\left(\mathrm{Fe}_{\mathrm{DCB}}\right)$. 


\section{- Área I - Área II}

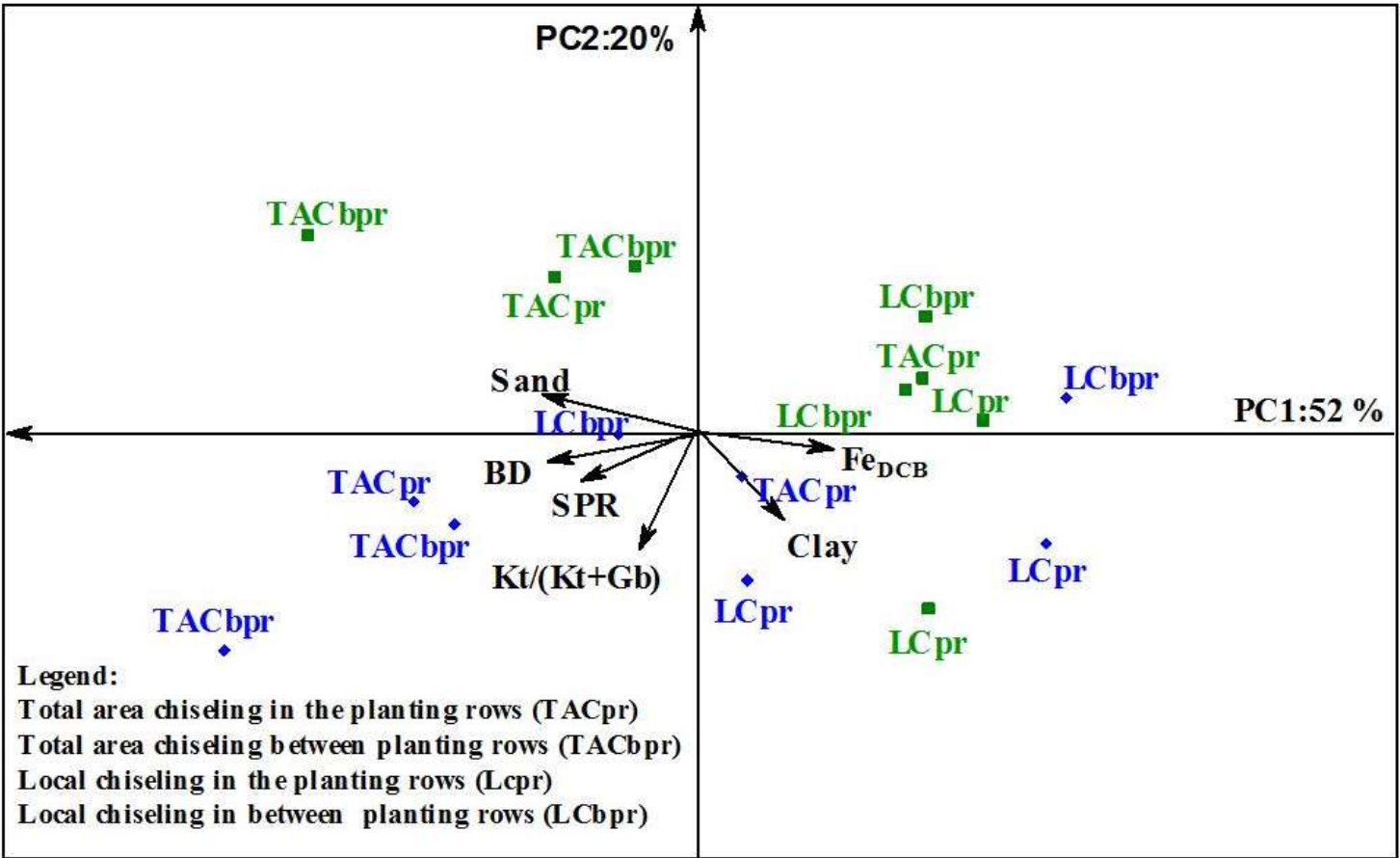

FIGURE 4. Graph of the principal components PC1 and PC2 in layer $0.40-0.60 \mathrm{~m}$, with the variables: soil penetration resistance (SPR), soil bulk density (BD), clay content, sand content, $\mathrm{Kt} /(\mathrm{Kt}+\mathrm{Gb})$ ratio and iron extracted by dithionite-citratebicarbonate $\left(\mathrm{Fe}_{\mathrm{DCB}}\right)$.

In layer $0.20-0.40 \mathrm{~m}$, the principal components PC1 and PC2 explained 76\% (PC1 50\% and PC2 26\%) of the variability of original variables (Figure 3 and Table 4). For PC1, the variables $\mathrm{Fe}_{\mathrm{DCB}}$, clay content, sand content, and $\mathrm{BD}$ were involved. As with the previous layer, the BD had an inverse correlation with clay content and $\mathrm{Fe}_{\mathrm{DCB}}$, while we observed a direct correlation with sand content.

In layer $0.40-0.60 \mathrm{~m}$, the principal components explained $72 \%$ (PC1 52\% and PC2 20\%) of the variability among original variables (Figure 4 and Table 4). There was the observation that BD and SPR were inversely correlated with $\mathrm{Fe}_{\mathrm{DCB}}$, as noted in previous layers (Table 4).

The graphs presented in Figures 1-4 showed no separation of areas with chiseling in the planting rows, and total area chiseling, as well as no divergence among samples taken from within and between rows. Thus, we suggest that the separation of the areas could be attributed to the mineralogical differences found between them.

The mineralogy of areas influenced the levels of BD and SPR, yet these attributes were not affected by soil preparation treatments. These results suggest that changes in physical attributes are not always correlated exclusively to soil management; in the current study these alterations appear to be the result of the mineralogy of the clay fraction.

Based on these results, the mineralogical assessment of soils should be adopted to better understand the variations in physical attributes. Furthermore, agricultural practices that look to improve the physical condition of soils and consequently their quality, should also be implemented. In this context, Area I, which had a greater $\mathrm{Kt} /(\mathrm{Kt}+\mathrm{Gb})$ ratio requires more frequent monitoring and the adoption of practices to improve the physical quality of the soil as this area showed a predisposition for compaction processes due to its mineralogy.
Therefore, management practices that are more conservative and cheaper, such as localized scarification, can be adopted, as we did not observe differences in the physical attributes of the soil when non-conservative management practices were used.

\section{CONCLUSIONS}

Both chiseling in the planting row and chiseling in the total area did not influence the physical attributes in the study areas. Soil attributes were associated with soil mineralogy; BD and SPR decreased in areas with elevated levels of iron oxide. On the contrary, the value of soil BD and SPR increased as kaolinite content increased.

Mineralogy could be adopted as an important tool to support soil management decisions in specific areas, thereby avoiding unnecessary management that could degrade the soil.

\section{ACKNOWLEDGEMENTS}

The São Martinho Usina for providing access to the experimental area. CAPES for providing funding for the study. FAPESP (São Paulo Foundation Research) (process $n^{\circ} 2012 / 20681-0 ; 2014 / 14490-2$ ) for the scholarship of the $4^{\text {th }}$ author and for financial assistance to conduct the research.

\section{REFERENCES}

Ajayi AE, Dias Júnior MS, Curi N, Gontijo I, AraújoJúnior CF, Vasconcelos Júnior AI (2009) Relation of strength and mineralogical attributes in Brazilian latosols. Soil and Tillage Research 102(1):14-18. DOI: https://doi.org/10.1016/j.still.2008.05.013 
Bahia ASRS, Marques Júnior J, Panosso AR, Camargo

LA, Siqueira DS, La Scala N (2014) Iron oxides as proxies for characterizing anisotropy in soil $\mathrm{CO}_{2}$ emission in sugarcane areas under green harvest. Agriculture, Ecosystems \& Environment 192:152-162. DOI: https://doi.org/10.1016/j.agee.2014.04.017

Bonetti JA, Anghinonia I, Moraes MT, Fink JR (2017) Resilience of soils with different texture, mineralogy and organic matter under long-term conservation systems. Soil and Tillage Research 174:(104-112). DOI: https://doi.org/10.1016/j.still.2017.06.008

Calonego JC, Raphael JPA, Rigon JPG, Neto LO, Rosolem CA (2017) Soil compaction management and soybean yields with cover crops under no-till and occasional chiseling. European Journal of Agronomy 85:31-37. DOI: https://doi.org/10.1016/j.eja.2017.02.001

Camargo AO, Moniz AC, Jorge JA, Valadares JMAS (eds) (1986) Métodos de análise química, mineralógica e física de solos do IAC. Campinas, Instituto Agronômico de Campinas, 94p.

Camargo LA, Marques Júnior J, Pereira GT (2013) Mineralogy of the clay fraction of alfisols in two slope curvatures. IV - Spatial correlation with physical properties. Revista Brasileira de Ciência do Solo 37(2):307-316. DOI: http://dx.doi.org/10.1590/S010006832013000200002

Camargo LA, Marques Júnior J, Pereira GT, Bahia ASRS (2014) Clay mineralogy and magnetic susceptibility of Oxisols in geomorphic surfaces. Scientia Agricola 71(3):244-256. DOI: http://dx.doi.org/10.1590/S010390162014000300010

Campos MCC, Montanari R, Marques Júnior J, Pereira GT, Souza ZM (2012) Caracterização de Argissolos em diferentes segmentos de vertente na região de Jaboticabal, SP. Revista de Ciências Agrárias / Amazonian Journal of Agricultural and Environmental Sciences 55(4):251-259.

Chen G, Weil RR, Hill RL (2014) Effects of compaction and cover crops on soil least limiting water range and air permeability. Soil and Tillage Research 136:61-69. DOI: https://doi.org/10.1016/j.still.2013.09.004

Claessen MEC (1997) Manual de métodos de análise de solo. Rio de Janeiro, Centro Nacional de Pesquisa de Solo, 212p.

Drees LR, Wilding LP, Smeck NE (1989) Silica in soils: quartz and disordered silica polymorphs. In: Dixon JB, Weed SB (eds). Minerals in soil environments. Soil Science Society of America, p.913-974.

Embrapa - Empresa Brasileira de Pesquisa Agropecuária (1997) Manual de métodos de análise de solo. Ministério da Agricultura e do Abastecimento, 212p.

Ghidin AA, Melo VF, Lima VC, Lima JMJC (2006) Topossequências de Latossolos originados de rochas basálticas no Paraná. I - Mineralogia da fração argila. Revista Brasileira de Ciência do Solo 30(2):293-306. DOI: http://dx.doi.org/10.1590/S0100-06832006000200011
Inda AV, Torrent J, Barrón V, Bayer C, Fink JR (2013) Iron oxides dynamics in a subtropical Brazilian Paleudult under long-term no-tillage management. Scientia Agricola 70(1):48-54. DOI: http://dx.doi.org/10.1590/S010390162013000100008

IPT - Instituto de Pesquisas Tecnológicas do Estado de São Paulo (1981) Mapa geomorfológico do Estado de São Paulo. IPT, 94p.

Jackson ML (1958) Soil chemical analysis. Prentice Hall, Inc., Englewood Cliffs, 591p.

Kaiser HF (1958) The varimax criterion for analytic rotation in factor analysis. Psychometrika 23(3):187-200.

Lu SG, Malik Z, Chen DP, Wu CF (2014) Porosity and pore size distribution of Ultisols and correlations to soil iron oxides. Catena 123:79-87.DOI:

https://doi.org/10.1016/j.catena.2014.07.010

Manyala Y-DB, Nemes A, Ranst EV, Mafuka P, De Pue J, Cornelis W (2015) Hierarchical pedotransfer functions to predict bulk density of highly weathered soils in Central Africa. Soil Science Society of America Journal 79(2):476-486. DOI:

http://dx.doi.org/10.2136/sssaj2014.06.0238

Mehra OP, Jackson ML (1960) Iron oxide removed from soils and clays by dithionite citrate system buffered with sodium bicarbonate. Clays and Clay Minerals 7(1):317-327. DOI: https://doi.org/10.1016/B978-0-08-009235-5.50026-7

Mestdagh MM, Vielvoye L, Herbillon AJ (1980) Iron in kaolinite: II. The relationship between kaolinite crystallinity and iron content. Clay Minerals 15(1):1-13. DOI: https://doi.org/10.1180/claymin.1980.015.1.01

Montanari R, Marques Júnior J, Campos MCC, Menezes Z, Camargo LA (2010) Caracterização mineralógica de Latossolos em diferentes feições do relevo na região de Jaboticabal, SP. Revista Ciência Agronômica 41(2):191-199.

Nunes MR, Pauletto EA, Denardin JE, Faganello A, Pinto LFS, Scheunemann T (2014) Persistence of chiseling effects on the compaction of a Nitisol under no-till in a humid subtropical region. Pesquisa Agropecuária Brasileira 49(7):531-539. DOI: http://dx.doi.org/10.1590/S0100-204X2014000700005

Pezarico CR, Vitorino ACT, Mercante FM, Daniel O (2013) Indicadores de qualidade do solo em sistemas agroflorestais. Revista de Ciências Agrárias 56:40-47. DOI: http://dx.doi.org/10.4322/rca2013.004

Ramos MR, Melo VF, Uhlmann A, Dedecek RA, Curcio GR (2015) Clay mineralogy and genesis of fragipan in soils from Southeast Brazil. Catena 135:22-28. DOI: https://doi.org/10.1016/j.catena.2015.06.016

Regelink IC, Stoof CR, Rousseva S, Weng L, Lair GJ, Kram P, Nikolaidis NP, Kercheva M, Banwart, S, Comans RNJ (2015) Linkages between aggregate formation, porosity and soil chemical properties. Geoderma 247-248:24-37. DOI: https://doi.org/10.1016/j.geoderma.2015.01.022 
Resende M, Curi N, Ker CJ, Rezende SR (eds) (2005) Mineralogia de solos brasileiros - Interpretações e aplicações. Lavras, UFLA, 187p.

Ryan PC, Huertas FJ (2013) Reaction pathways of clay minerals in tropical soils: insights from kaolinite-smectite synthesis experiments. Clays and Clay Minerals 61(4):303-318. DOI:

https://doi.org/10.1346/CCMN.2013.0610410

Souza MZ, Marques Júnior J, Pereira TG (2009) Spacial Variability of the Physical and mineralogical properties of the soil from the areas with variation on landscape shapes. Brazilian Archives of Biology and Technology 5: 305-316. DOI: http://dx.doi.org/10.1590/S1516-89132009000200007
Suzuki LEAS, Lima CLR, Reinert DJ, Reichert JM, Pillon CM (2014) Estrutura e armazenamento de água em um Argissolo sob pastagem cultivada, floresta nativa e povoamento de eucalipto no Rio Grande do Sul. Revista Brasileira de Ciência do Solo 38(1):94-106. DOI: http://dx.doi.org/10.1590/S0100-06832014000100009

Tormena CA, Silva AP, Libardi PL (1998) Caracterização do intervalo hídrico ótimo de um Latossolo Roxo sob plantio direto. Revista Brasileira de Ciência do Solo 22(4):573-581. DOI: http://dx.doi.org/10.1590/S0100-06831998000400002

Wu X, Cai C, Wang J, Wei Y, Wang S (2016) Spatial variations of aggregate stability in relation to sesquioxides for zonal soils, South-central China. Soil and Tillage Research 157:11-22. DOI: https://doi.org/10.1016/j.still.2015.11.005 